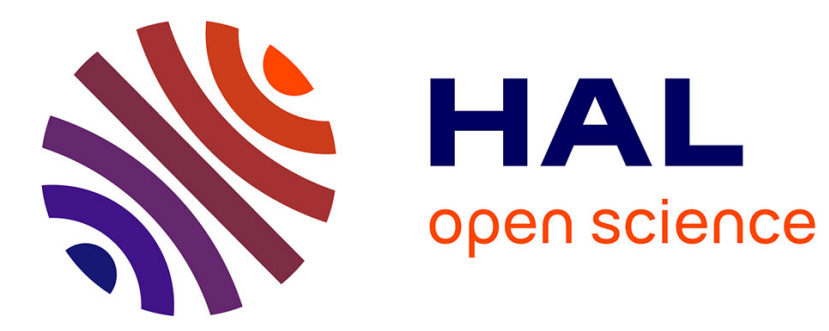

\title{
New Developments in Ferrite Plating
}

M. Abe

\section{- To cite this version:}

M. Abe. New Developments in Ferrite Plating. Journal de Physique IV Proceedings, 1997, 07 (C1), pp.C1-467-C1-470. 10.1051/jp4:19971190 . jpa-00254840

\section{HAL Id: jpa-00254840 https://hal.science/jpa-00254840}

Submitted on 1 Jan 1997

HAL is a multi-disciplinary open access archive for the deposit and dissemination of scientific research documents, whether they are published or not. The documents may come from teaching and research institutions in France or abroad, or from public or private research centers.
L'archive ouverte pluridisciplinaire HAL, est destinée au dépôt et à la diffusion de documents scientifiques de niveau recherche, publiés ou non, émanant des établissements d'enseignement et de recherche français ou étrangers, des laboratoires publics ou privés. 


\title{
New Developments in Ferrite Plating
}

\author{
M. Abe \\ Department of Physical Electronics, Tokyo Institute of Technology O-okayama, Meguro-ku, Tokyo, 152, \\ Japan
}

\begin{abstract}
The ferrite plating - a method synthesizing ferrite films from an aqueous solution - has developed lately as follows; (1) Applying power ultrasound to aqueous solution improves the qualities of ferrite coating on polymer microspheres much, (2) similarity is found between mechanisms of the ferrite plating and bacterial $\mathrm{Fe}_{3} \mathrm{O}_{4}$ (magnetsome) synthesis, (3) using highly alkaline ( $\mathrm{pH}=13$ ) solution containing a chelating agent increases the solubilities of such particular ions as $\mathrm{Mn}^{2+}$ and $\mathrm{Ba}^{2+}$ in ferrite-plated films, and (4) $\mathrm{Fe}_{3} \mathrm{O}_{4} / \mathrm{CdS}$ multilayer films are synthesized from a wet chemical process. Applications are proposed of ferrite-plated films to (5) backlayers for $\mathrm{CoCr}$ perpendicular magnetic recording media, (6) contrast agents for ultrasonography, and (7) catalyst for decomposing aqueous residual chlorine.
\end{abstract}

\section{INTRODUCTION}

The ferrite plating invented by M. Abe and Y. Tamaura [1] facilitates synthesis of crystalline spinel ferrite films from an aqueous solution below $100^{\circ} \mathrm{C}$. Requiring no heat treatment, ferrite plating enables us to fabricate ferrite film magnetic devices on substrates of such non-heat-resistant materials as plastics [2].

The surface of ferrite-plated films have a strong compatibility with water and organic compounds, which opened the door to various electrochemical and biomedical applications: Polymer submicron microspheres with surface ferrite-plated with magnetite have been put to practical clinical use as carriers for enzyme immunoassay, a cancer marker [3]. The purpose of this paper is to describe developments attained in the ferrite plating after the ICF 6 (1992) [4] .

\section{DEVELOPMENTS IN FERRITE PLATING}

\subsection{Ultrasound enhanced ferrite plating [5]}

The ferrite plating was combined with sonochemical technology, an application of power ultrasound to stimulate chemical processes in liquids. Currently sonochemistry is attracting special interest in fields of chemistry and chemical engineering, since it causes novel chemical and physical reactions due to localized " hot spots " of extremely high temperature ( $\sim 5000 \mathrm{k})$ and high pressure $(\sim 1000 \mathrm{~atm})$ generated by collapse of cavitation bubbles $[6]$. As Figure 1 shows, we $[5]$ applied a power ultrasound $\left(19.5 \mathrm{kHz}, 600 \mathrm{~W}\right.$ ) to an aqueous solution ( $\mathrm{pH}=7, \mathrm{~T}=65^{\circ} \mathrm{C}, 500 \mathrm{ml}$ ) of $\mathrm{FeCl}_{2}+\mathrm{NaNO}_{2}+\mathrm{NH}_{4} \mathrm{OH}$ containing polyacrylate microspheres, $0.25 \mu \mathrm{m}$ in diameter, as substrates. The surface of the spheres were successfully encapsulated with a continuous magnetite layer ( Fig. 2 (b) ) with magnetization reaching $95 \%$ of that reported for bulk $\mathrm{Fe}_{3} \mathrm{O}_{4}$ sample. This makes a marked contrast with the previous results of experiments without applying ultrasound waves: When the spheres were smaller than $\sim 0.3 \mu \mathrm{m}$ in diameter, the magnetite coat did not encapsulate the surface but formed islands ( Fig. 2 (a) ) [7], whose magnetization was less than $\sim 40 \%$ of the bulk sample value. The outstanding improvements obtained in the surface area and the magnetization of the ferrite coating will improve the sensitivity of the enzyme immunoassay, or cancer marker, which has been put to practical clinical use utilizing the microspheres with island-shaped ferrite coating [3].

\subsection{Bacterial $\mathrm{Fe}_{3} \mathrm{O}_{4}$ formation and ferrite plating [8]}

A close relation has been found between the ferrite plating and the biomineralization of $\mathrm{Fe}_{3} \mathrm{O}_{4}$ as follows: 
[ I ] In vitro experiments using an enzyme, cytochrome $\mathrm{cd}_{1}$, extracted from magnetotactic bacteria suggested that the magnetosomes ( $\mathrm{Fe}_{3} \mathrm{O}_{4}$ single crystals ) are synthesized from an aqueous solution of $\mathrm{Fe}^{2+}$ via oxidation of $\mathrm{Fe}^{2+}$ to $\mathrm{Fe}^{3+}$ by $\mathrm{NaNO}_{2}$ activated by the enzyme [9]. The $\mathrm{Fe}^{2+} \rightarrow \mathrm{Fe}^{3+}$ oxidation plays an essential role also in the ferrite plating, for which $\mathrm{NaNO}_{2}$ has been found to be the most expedient oxidizing reagent.

[II] In the biological formation of $\mathrm{Fe}_{3} \mathrm{O}_{4}[10,11]$ found in the denticles (small teeth) of chiton, a shellfish, the $\mathrm{Fe}_{3} \mathrm{O}_{4}$ coating is formed on apatite irtermediated by $\gamma-\mathrm{FeOOH}-$ a ferric hydroxy oxide formed in the ferrite plating as a precursor, on which $\mathrm{Fe}^{2+}$ ions are adsorbed to yield the mixed valence compound of $\mathrm{Fe}_{3} \mathrm{O}_{4} \quad$ [12].

Therefore, it is suggested that, in both the biological and the ferrite-plating syntheses of $\mathrm{Fe}_{3} \mathrm{O}_{4}$, the $\mathrm{Fe}^{2+}$ ions are oxidized by $\mathrm{NaNO}_{2}$ to $\mathrm{Fe}^{3+}$ to form $\gamma-\mathrm{FeOOH}$ as the precursor, on which $\mathrm{Fe}^{2+}$ ions are adsorbed to react to $\mathrm{Fe}_{3} \mathrm{O}_{4}$.

\subsection{Chelate ferrite plating}

Conventional ferrite plating has been performed using a neutral aqueous solution at $\mathrm{pH}=6 \sim 7$, because $\mathrm{Fe}^{2+}$ ions are adsorbed on solid surface (which is an essential reaction step in the ferrite plating) only when $\mathrm{pH}>\sim 6$, and are precipitated when $\mathrm{pH}>\sim 8$. In the neutral solution, the adsorption rates of such ions as $\mathrm{Mn}^{2+}, \mathrm{Ni}^{2+}$ and $\mathrm{Ba}^{2+}$ are so low that the plated films contain only low concentration of such ions. We $[13,14]$ overcame this deficiency by using an aqueous solution containing $\mathrm{KNaC}_{4} \mathrm{H}_{4} \mathrm{O}_{6}$ (Rochelle salt), a chelate agent making complexes of $\mathrm{Fe}^{3+}$ and other metal ions which are not precipitated even when the pH is very high. We call this "chelate ferrite plating."

From a chelated highly alkaline ( $\mathrm{pH}=13$ ) solution, we [13] obtained films of $\mathrm{Mn}_{x} \mathrm{Zn}_{y} \mathrm{Fe}_{3-x-y} \mathrm{O}_{4}$ with concentration of $\mathrm{Mn}$ up to $\mathrm{x}=1.5$, which is much higher than the solubility limit, $\mathrm{x}=0.12$, obtained from a neutral solution. From another chelated alkaline solution, Ba-containing oxide films were successfully synthesized up to a metal concentration ratio of $\mathrm{Ba} / \mathrm{Fe}=0.16$, though they were $\mathrm{X}$-ray amorphous and fenomagnetic $\mathrm{BaFe}_{12} \mathrm{O}_{19}$ phase appeared only when heated above $800^{\circ} \mathrm{C}[14]$.

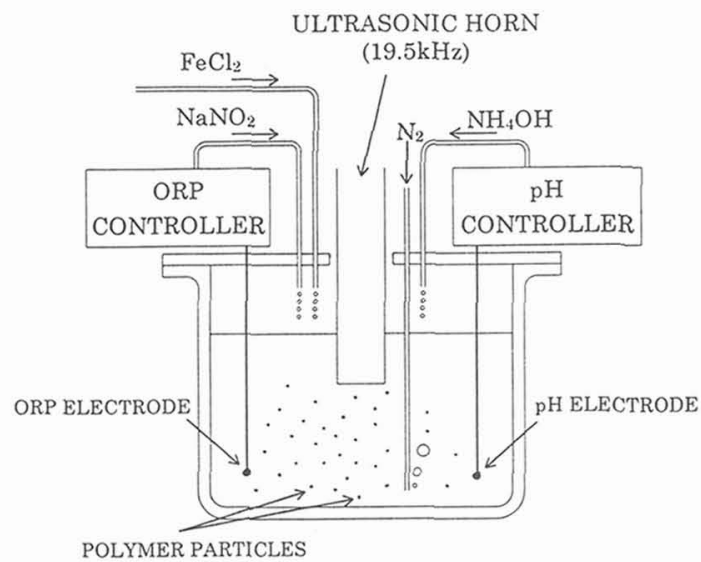

Fig. 1: Apparatus for power ultrasound enhanced ferrite plating for polymer particles. (a)

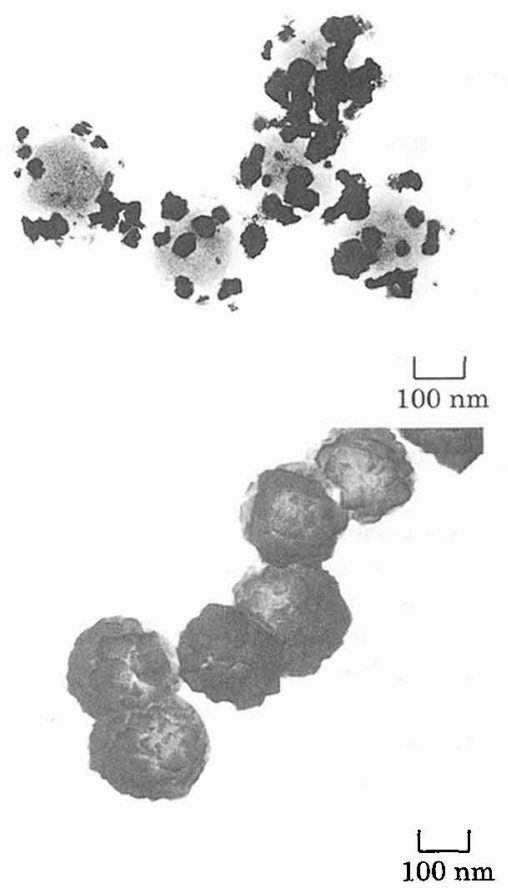

Fig. 2: (a): TEM abservation of polyacrylate spheres, 0.25 $\mu \mathrm{m}$ in diameter, which were ferrite-plated without ultrasound enhancement. (b): SEM observation of similar, but ferrite plated with uitrasonic enhancement, spheres. 


\section{$2.4 \mathrm{Fe}_{3} \mathrm{O}_{4} / \mathrm{CdS}$ multi-layer films $[15,16]$}

Combining the ferrite plating with another chemical method for synthesizing CdS, we $[15,16]$ prepared $\mathrm{Fe}_{3} \mathrm{O}_{4}$ $/ \mathrm{CdS}$ multi-layer films ( Fig. 3 ) from aqueous solution on glass substrates. A mixed solution ( $\mathrm{pH}=6.8$ ) of $\mathrm{FeCl}_{2}$ and $\mathrm{NaNO}_{2}$ and another ( $\mathrm{pH}=7-8$ ) of $\mathrm{CdCl}_{2}$ and $\mathrm{CH}_{3} \mathrm{CSNH}_{2}$ were alternately poured onto the substrate surface in order to synthesize $\mathrm{Fe}_{3} \mathrm{O}_{4}$ and $\mathrm{CdS}$ layers, respectively, at $80^{\circ} \mathrm{C}$. The saturation magnetization of the $\mathrm{Fe}_{3} \mathrm{O}_{4}$ layers decreased as their thickness decreased ( from $1600 \AA$ to $320 \AA$ ), possibly indicating a decrease in magnetization in surface, or intersurface layer.

\subsection{Backlayer for $\mathrm{CoCr}$ perpendicular magnetic recording media}

We [17] have proposed that, soft ferrite layer made by the ferrite plating may be used as a high performance backlayer for $\mathrm{CoCr}$ perpendicular magnetic recording media, as shown in Fig. 4. It will suppress the eddy current loss which is inherent in the conventional permalloy metal back layer at high frequency, as has been shown by the experiments using bulk-ferrite substrates $[18]$.

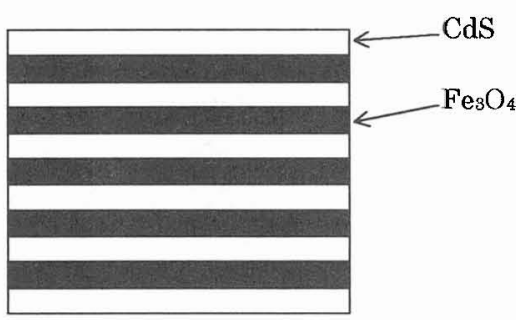

Fig. 3: Maltilayered films of $\mathrm{Fe}_{3} \mathrm{O}_{4} / \mathrm{CdS}$.
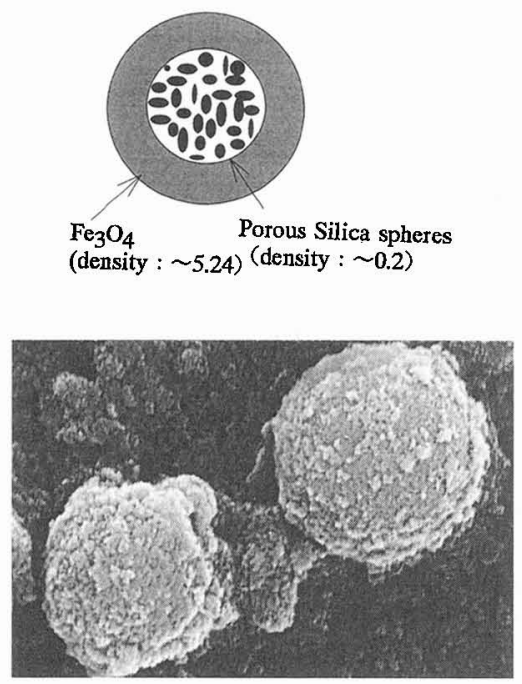

$\operatorname{lum}$

Fig. 5: Structure and SEM observation of ferrite-capsulated porous silica spheres for ultrasonic contrast agents.

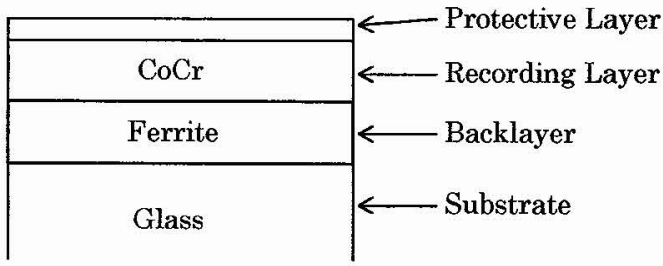

Fig. 4: Structure of hard disk with $\mathrm{CoCr}$ perpendicular magnetic layer on highly-permeable ferrite underlayer made by ferrite plating.

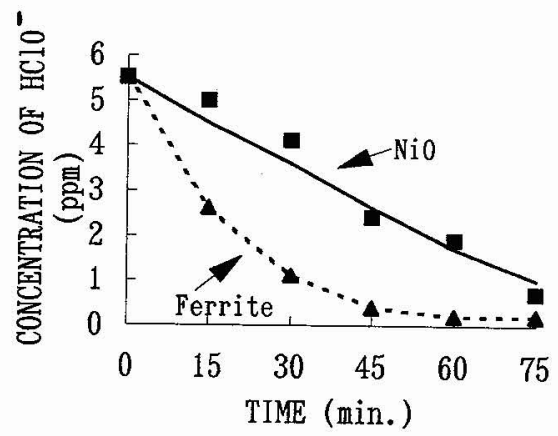

Fig. 6: Catalytic decomposition of aqueous solution $(8 \mathrm{ml})$ of $\mathrm{NaHClO}$, by $\mathrm{Fe}_{3} \mathrm{O}_{4}$-plated stainless steel sheet and $\mathrm{Ni}$ sheet ( with natural NiO layer on the surface). Both sheets are the same in size $\left(10 \times 100 \times 0.2 \mathrm{~mm}^{3}\right)$, but the former has much wider surface area, which is yet to be measured, than the latter. 


\subsection{Contrast agents for ultrasonography $[19]$}

We $[20]$ have proposed that porous silica microspheres $\left(1 \sim 3 \mu \mathrm{m}\right.$ in diameter ) encapsulated with $\mathrm{Fe}_{3} \mathrm{O}_{4}$ by the ferrite plating, as shown in Fig. 5, can be a new type of magnetically-controllable contrast agents for clinical and industrial sonography. The air trapped in the pores of the porous silica strongly scatters ultrasound waves. The novel contrast agents can be adjusted in their virtual specific gravity to that of ambient fluid. Imaging still and flowing waters have been successfully attained by the ferrite capsulated porous silica spheres [21].

\subsection{Catalyst for decomposing residual chlorine}

We found that the $\mathrm{Fe}_{3} \mathrm{O}_{4}$ layer deposited on stainless steel substrate by the ferrite plating functions as a strong catalyst for decomposing residual chlorine in water, as shown in Fig. 6. Utilizing the catalytic activity of $\mathrm{Fe}_{3} \mathrm{O}_{4}$ or $\mathrm{NiO}$, a sensor detecting the concentration of residual chlorine, which is put in water for disinfection, has been proposed by the author.

\section{CONCLUDING REMARKS}

At present the ferrite plating is the only method by which we can synthesize inorganic oxide films from an aqueous solution without using electric current. Performed under low temperature $\left(<100^{\circ} \mathrm{C}\right)$ and ambient pressure without using expensive apparatus, the ferrite plating is advantageous for industrial production. Owing to the developments described in this paper, the ferrite plating is now expected to find a wider range of application.

\section{References}

[1] M.Abe and Y. Tamaura, Jpn. J. Appl. Phys., 22 (1983) L511-L513.

[2] M. Abe, T. Itoh and Y. Tamaura, Thin Solid Films, 216 (1992) 155-161.

[3] I. Nishizono, S. lida, N. Suzuki, H. Kawada, H. Murakami, Y. Ashihara, and M. Okada, Clin. Chem., 37 (1991) 16391644.

[4] M. Abe, Ferrites: Proc. Int. Con. Ferrites (ICF 6), Tokyo-Kyoto, Japan, 1992, Jpn. Soc. Powder Powder Metal., pp. 472477.

[5] Y. Kitamoto, M. Zhang, S. Haijima, K. Matsumoto and M. Abe, Submitted to Proc. ICF 7, Bordeaux, 1996.

[6] T. J. Mason, Chem. Industry, 18 January (1993) 47-50.

[7] S. Nagahata, M. Sasaki, K. Yoshida, M. Anan and M. Abe, Proc. ICF 6, Tokyo-Kyoto, 1992, $279-281$.

[8] M. Abe and Y. Tamaura, Submitted to Proc. ICF 7, Bordeaux, 1996.

[9] T. Yamazaki, H. Oyanagi, T. Fujiwara and Y. Fukumori, Eur. J. Biochem., 233 (1995) 665-671.

[10] H. A. Lowenstam, Science, 156 (1967) 1373-1375.

[11] Y. Yamada and M. Mizota, Kotai Butsuri (Solid State Physics) 19 (1984) 52-60 [in Japanese].

[12] Y. Tamaura, M. Saturno, K. Yamada and T. Katsura, Bull. Chem. Soc. Jap., 57 (1984) 2417-2421.

[13] S. Haijima, T. Miki, T. Itoh and M. Abe, Nihon Oyojiki Gakkaishi [J. Magn. Soc. Jpn.], 20 (1996) $485-487$ [in Japanese].

[14] T. Itoh, T. Miki, Q. Zhang, M. Abe and Y. Tamaura, Jpn. J. Appl. Phys., 34 (1995) 1534-1536.

[15] T. Miki, T. Itoh and M. Abe, Nihon Oyojiki Gakkaishi [J. Magn. Soc. Jpn.], 20 (1996) 317-320 [in Japanese] .

[16] M.Abe, T. Miki and Y. Kitamoto, Submitted to Proc. ICF 7, Bordeaux, 1996.

[17] M. Abe, T. Itoh and Q. Zhang, “Advanced Materials ' 93, II/B: Information Storage Media," Proc. IUMRS' 93, Tokyo, 1993, 15B pp. 1117-1122.

[18] S. Yamamoto, A. Fujiwara, I. Watanabe, K. Ouchi and Y. Nakamura, J. Magn. Soc. Jpn. Suppl., 15 (1991) No. S2 293-298.

[19] M.Zhang, Y. Kitamoto and M. Abe, Submitted to Proc. ICF 7, Bordeaux, 1996.

[20] M. Zhang, O. Zhang, T. Itoh and M. Abe, IEEE Trans. Magn., 30 (1994) 4692-4694.

[21] M. Zhang, T. Itoh and M. Abe, Submitted to Jpn. J. Appl. Phys. 